\title{
児童の運動能力と心理的特性に関する研究
}

\author{
戸 村 博 之( 葛南工莱高等学校) \\ （昭和52年12月12日 受付）
}

\section{A Study of the Relationship Between Motor Ability and Mental Characteristics of Children}

\author{
Hiroyuki TOMURA*
}

\begin{abstract}
With 637 primary school children of the second, fourth and sixth grades (including 317 boys and 320 girls), the motor ability test and three mental tests (the sociometric test, the Y-G personality test and the adjustment test) were administered and the relationship between motor ability and mental characteristics (social status, personality and adjustment) was analysed.

The results are as follows:

1. The children who were superior in motor ability were more popular and were liked better than those who were inferior in this ability among the same grade groups: the children who were popular in the group were superior in motor ability to those who were disliked and isolated. Such a tendency was more pronounced in boys than in girls, and in lower grades than in higher ones.

2. In the relationship between motor ability and personality, there was a little difference between sexes and grades. But it was proved that the group who were superior in motor ability were more stable emotionally, more lively in action and had greater social leadership than the group rated inferior in motor ability.

3. In motor ability and adjustment, there were some differences between boys and girls. The boys who were superior in motor ability showed better adjustment to themselves and society than the boys rated inferior in motor ability. However, in the case of girls, the tendency was not so pronounced as observed in the boys. (Hiroyuki Tomura : A Study of the Relationship Between Motor Ability and Mental Characteristics of Children Jap. J.
\end{abstract} Phys. Educ., Vol. 23, No. 2, Sept., 1978, pp. 173 181)

\section{腥瀻}

運動能力の発達が社会性の発達や情緒の発達に どのような影響を及ぼしているのかを知ること は，体育のより効果的な指導をすすめていく5党
で極めて重要なことである．従来この 種の問題 は, 運動能力テストの得点と sociometric test および性格検查などの得点との相関を求めるとい

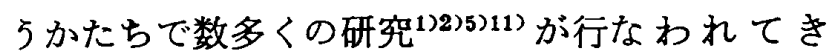
た.しかしながら、これらの研究の多くは高校

* Katsunan Technical High School, Hirata, Ichikawa, Chiba (272) 
生, 大学生, 特にスポーツ 選手を対象としたすの であり，子どもを対象とした研究は比較的少な (7).

児童の身体・運動能力と社会的地位の関係につ いて調查した H. H. Clarke $5^{3) 4}$ は, 背が高く, 運動能力の優れた者に仲間の人気があつまり，集 団の中で高い地位が与えられていると報告してい る。また，L. N.McGraw ら8)は，走・跳・投など 一般的運動能力の㑩れた者に高い地位を与えられ る傾向が認められ，特に競技参加の経験との相関 があることを明らかにしている，さらに，友人関 係の分化とその発達的傾向について調べた石黒 ${ }^{6)}$ の研究では，遊び仲間としては類似しているも の，親和感によるものおよび身体運動能力の優秀 なものを友人として求めるという結果が見出され ている.

一方, 運動能力と性格との関係について検討し た G.L. Rarickeら ${ }^{15)}$ は，運動能力の優れた児童 は贫った児童よりも社会的な適応がよく，また， 性格的には活動的で，おだやかで，機知に富み， 注意深く，協力的であると報告している，さら に，性格をとりあげた松田ら ${ }^{10)}$ ，直塚ら ${ }^{13)}$ および K. Tillman 5 ${ }^{18)}$ の研究でも, Rarick らの研究と ほぼ一致する結果を得ている。

このよ5に, 小学生, 中学生を対象とした従来 の研究報告は，運動能力の僈れた者が劣った者よ りも集団の中で高い社会的地位を与えられてお り，性格面でも好ましい傾向が認められることを 示唆している.しかし，これらの研究の多くは男 子を対象としたものであり，女子については，ま だ十分に明らかにされていない。また，運動能 力と社会的地位および性格との関係は年龄が高く なるにつれてどのよ5に変化するのか，について 考察した研究は極めて数が少ない，さらに，適応 性に関しての問題は，上述の社会的地位や性格の 研究の中で多少言及されているものの，まだ十分 に解明されていない例域である。

本研究では，上記の問題点を考虑しながら，児 童の運動能力と心理的特性（社会的地位, 性格, 適応性）との関係について, 以下の観点から検討 することをめさした。

1）運動能力の優れた考と劣った者の社会的地

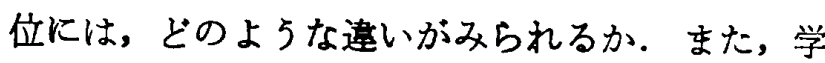
級で人気をあつめている者と孤立したり，排斥さ れている者の運動能力に差がみられるか.

2）運動能力の優れた者と劣った者の性格特性 には，どのような違いがみられるか。また，性格

(類型)によって運動能力に差がみられるか.

3）運動能力の優れた者と劣った者の適応のし かたには，どのよらな違いがみられるか。また， 適芯の良い者と悪い者の運動能力に差がみられる か.

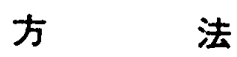

1. 調査期間

1976年 6 月～ 7 月

2. 対象

八千代市立八千代台東小学校児童 2 年 172 名 (男86, 女 86)， 4 年 233 名 (男 121，女 112)，6 年 232 名（男110，女122），計637名.

3. 测定種目および結果の処理

1）運動能力テスト

運動能力テストとして，2 年では(1)25 m走, (2) 立ち幅とび，(3)ソフトボール投げ，(4)体支持持続 時間，(5)連続とび越しの5 種目をとりあげた。 ま た， 4 年と 6 年では以下の 13 種目をとりあげた。 (1)50 m走，(2)走り幅とび，(3)ソフトボール投げ， (4)斜め䯚垂腕届伸，(5)ジグザグドリブル，(6)連続 さかあがり，(7)反復横とび，(8)垂直とび，(9)背筋 力, (10)挃力, (11)伏臥上体そらし, (12立位体前届, (13踏久台昇降運動 ( 6 年男子のみ)

テストは「小学校 $1 \cdot 2$ 年生の運動 能力テス

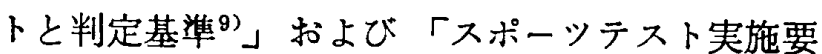
覧 ${ }^{14)} 」$ に従って実施した。テストの結果は, 各学 年とも男女別, 種目別に平均之標準偏差を算出 し，それを用いて個人の成績をすべてT得点に換 算した。群構成は各種目 T得点の総合点の高い方

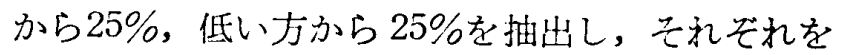
上位群，下位群とした。

2) sociometric test

この調査は記名方式で，あそびの場面の選択基 準を用いた。それぞれの質問に対し男子は男子, 女子は女子の友人名を同じ組の中から 3 名列挙さ せる制限選択法とし，列挙した各々についてその 
理由を書かせた。また，実施に先だち，この調查 は組の人たちが楽しくなるようにするために行な らこと，思ったとおり正直に書くこと，相談した り見せ合ったりしないことなどを注意した。ささら に，低学年については，特に時間をかけるよう配 虑した。

調査票の主要部分は次のとおりである.

(1)がっこ5でややすじかんなどに，ヒゅうに はなしあったり，あそんだりするときこのくみ のなかのだれといっしょになりたいとおもいます か.そのひとのみょらじとなまえを，いっしょに なりたいじゅんばんに 3 人かいてください。

(2)がっこ5で，やすみじかんなどに，じゆうに はなしあったり，あそんだりするとき，このくみ のなかでいっしょになりたくないとおもうひと がいますか。もしいたら，そのひとのみょうじと なまえを，いっしょになりたくないじゅんばんに 3 人かいてくたさい。

調査結果の整理は，各学年ともンシオマトリッ クスを男女別，学級別に作成し，個人の特性に関 する指数，すなわち，選択地位 (choice status), 排斥地位(rejection status), および社会的地位指 数 (social status index) を次の式を用いて算出 した ${ }^{16}$.

(1) $\mathrm{C} \mathrm{S}=\Sigma \mathrm{Cr} / \mathrm{N}-1$

(2) $\mathrm{R} \mathrm{S}=\Sigma \mathrm{Rr} / \mathrm{N}-1$

(3) $\mathrm{S} \mathrm{S} \mathrm{I}=\left(\Sigma \mathrm{Cr}+\sum \mathrm{Rr}\right) / \mathrm{N}-1$

$\mathrm{Cr}:$ 受计た選択数

$\mathrm{Rr}$ : 受けた排斥数

次に本研究では，一応便宜的ではあるが，下記 のよらな規準でもって人気兒童，排斥児童およで 孤立児童の抽出を行なった。

(1) 人気児童

4 年男子および 4 年女子では C S . 30 以上, そ
の他の学年では C S.25 以上をもってその学級の 人気児童とした。この規準の設定については，資 料を通覽した場合，ＣSの分布状況からして大体 指数.25および.30の㲽でそれぞれ段階区分がつい たからである。排斥児童および孤立児童でもそれ ぞれの決定規準で同様なことがいえる。

\section{(2) 排斥児童}

2 年男子では R S. 30 以上，その他の学年では R S.25 以上をむってその学級の排斥されている 児童とした。なお，該当する児童がいなかった学 級（4 年男子 1 学級， 4 年女子 1 学級， 6 年女子 1 学級）からは抽出しなかった。

(3) 孤立児童

積極的選択においても，拒否的選択においても 共にあまり級友から指名されない児童として，操 作的には S S I .10 以下の者をその学級の孤立児 童とした。なお，該当する児童がいなかった 4 年 女子の 1 学級からは抽出しなかった。

男女別, 学年別の抽出人数は表 1 に示す通りで ある。

\section{3）性格検查}

性格特性の測定には，矢田部・ギルフォード性 格検查一学童用 ${ }^{17}$ - ( (以下 $Y-G$ 検査と略記する) を用い，検查は同検查実施手引に従って実施し た。性格の分類は，各個人の尺度点をプロフィー ル化し， A, B, C, D, E 型の 5 類型に分類し た。な拈，性格類型の分類にあたっては，比較的 顕著なタイプの者を抽出するため, 得点プロフィ ールが典型または準型を示したものをとりあげ， 混合型および判定不能などは分類の対象から除い た。

4）適応性診断テスト

啇応性の㡣断には，長島貞夫らの「適応性診断 テスト」を年用いた。このテストは，児童が当面

表 1 人気児童, 排斥児童括よび坬立児童の抽出人数

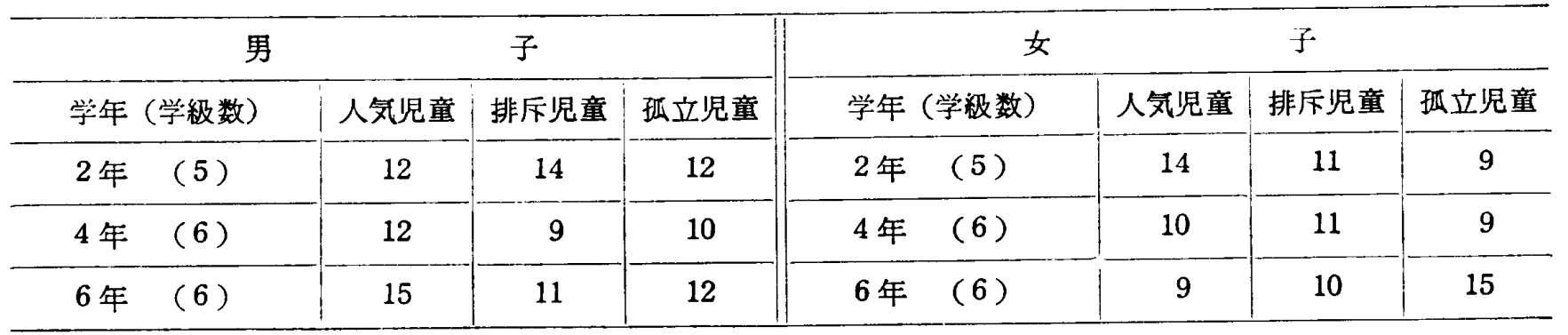


している環境条件や日常の問題場面において，ど のよ5に適応しているか，さらに，正常にして幸 福なかつ社会的に有用なパーソナリティを発展せ しめつつあるかどうかを検查するために作成さ れ，標準化されたものであるテテストの構造は， (1)異常傾向, (2)神経質傾向, (3)自尊感情, (4)退避 的傾向，(5)自己統制，(6)社会的技術，(7)統率性， (8)家庭関係，(9)学校関係，(10)近隣関係の 10 個の特 生から成り，各特性は15の質問項目から構成され ている.

このテストは，6 年の児童を対象とし，テスト の実施と結果の処理については，同テスト解説に 従った。 また各個人の総点を算出し，男女別に高 い方から $25 \%$ ，低い方から 25\%を抽出して，それ ぞれを適応群，不適応群とした。

\section{結果}

1. 運動能力と社会的地位の関係

表 2 運動能力上位群と下位群のC S, R S および S S I の高い者と低い者の人数（男子）

\begin{tabular}{|c|c|c|c|c|c|c|c|}
\hline & 2 & 年 & 4 & 年 & 6 & 年 \\
\hline & & \multicolumn{6}{|c|}{ 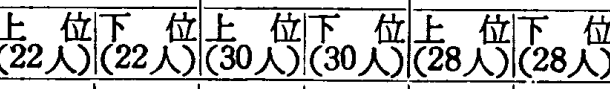 } \\
\hline \multirow{2}{*}{ C S } & 滈 & 18 & 3 & 18 & 11 & 18 & 10 \\
\hline & 低 & 4 & 19 & 12 & 19 & 10 & 18 \\
\hline \multirow{2}{*}{ R S } & 高 & 12 & 10 & 15 & 15 & 14 & 13 \\
\hline & 低 & 10 & 12 & 15 & 15 & 14 & 15 \\
\hline \multirow{2}{*}{ S S I } & 高 & 13 & 9 & 21 & 9 & 17 & 11 \\
\hline & 低 & 9 & 13 & 9 & 21 & 11 & 17 \\
\hline
\end{tabular}

表 3 運動能力上位群と下位群のC S, R S 打よび S S I の高い者と低い者の人数（女子）

\begin{tabular}{|c|c|c|c|c|c|c|c|}
\hline & 2 & 年 & 4 & 年 & 6 & 年 \\
\hline & & \multicolumn{6}{|c|}{ 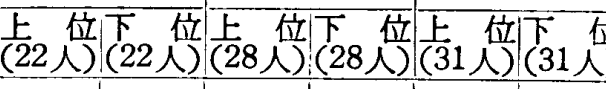 } \\
\hline \multirow{2}{*}{ C S } & 高 & 14 & 8 & 19 & 9 & 17 & 14 \\
\hline & 低 & 8 & 14 & 9 & 19 & 14 & 17 \\
\hline \multirow{2}{*}{ R S } & 高 & 8 & 14 & 7 & 19 & 16 & 14 \\
\hline & 低 & 14 & 8 & 21 & 9 & 15 & 17 \\
\hline \multirow{2}{*}{ S S I } & 高 & 11 & 11 & 15 & 13 & 16 & 15 \\
\hline & 低 & 11 & 11 & 13 & 15 & 15 & 16 \\
\hline
\end{tabular}

表 2 および表 3 は, 男女別, 学年別に運動能力 上位群と下位群の C S， R Sおよび S S I の高い 者と低い者の人数を示したものである．男女別， 学年別にそれぞれ人数での群差をみたところ， 男子では 2 年のC S $\left(x^{2}=20.497, \mathrm{df}=1, \mathrm{P}<\right.$ $0.01), 4$ 年の S S I $\left(x^{2}=9.600, \mathrm{df}=1, \mathrm{P}<\right.$ $0.01)$ および 6 年のC S $\left(x^{2}=4.571, \mathrm{df}=1, \mathrm{P}\right.$ ０.05）で有意差が認められた。つまり， 2 年と 6 年では，上位群が下位群よりもC S の高い者が 多く, 4 年では, 上位群が下位群よりるSSI の高い 者が多かった。また， 4 年の上位群は下位群よりも C Sの高い者が多い傾向がみられた $\left(x^{2}=3.270\right.$, $\mathrm{df}=1, \mathrm{P}<0.10)$. 一方, 女子では 4 年の C S $\left(x^{2}\right.$ $=7.143, \mathrm{df}=1, \mathrm{P}<0.01)$ そ R S $\left(x^{2}=10.338\right.$, $\mathrm{df}=1, \mathrm{P}<0.01 ）$ で有意差が認められた。すなわ ち，上位群は下位群よりもC S の高い者が多く， R Sの低い者が多かった。 また，2 年では，上位 群が下位群よりもC Sの高い者が多く， R S の低 い者が多い傾向がみられた（いずれも $x^{2}=3.273$ ， $\mathrm{df}=1, \mathrm{P}<0.10)$.

次に人気児童と排斥児童および孤立児童との運 動能力を比較してみた。表 4 と 5 に示されている よ5に，男子，女子ともに，2 年と 4 年の人気児 童は排斥児童および孤立児童よりも運動能力で優 れている傾向がみられるが， 6 年では群間に差が みられない，平均值の差の有意性を検 定した結 果, 男子では 2 年の人気児童と排斥児童間 $(t=$ $2.20, \mathrm{df}=24, \mathrm{P}<0.05)$, 人気児童子孤立児童間 $(\mathrm{t}=3.12, \mathrm{df}=22, \mathrm{P}<0.01)$ および 4 年の人気 児童と排斥児童間 $(t=2.92, d f=19, P<0.01)$, 人気児童と孤立児童間 $(t=3.11, d f=20, P<$ 0.01）でそれぞれ有意差が認められた，女子では 4 年の人気児童と排斥児童間 $(\mathrm{t}=2.24, \mathrm{df}=19$, $\mathrm{P}<0.05)$ で有意差が認められた。

\section{2. 運動能力と性格の関係}

図 1 は男女別, 学年別に運動能力上位群之下位 群の $\mathrm{Y}-\mathrm{G}$ 検査プロフィールを比較したものであ る、四から明らかなよ5に，男子，女子ともに平 均プロフィールはほとんどがA（平凡）型である が，上位群は下位群と比較するとやや右下がり （安定積極）傾向を示しており，下位群は上位群 と比較するとわずかではあるが左下がり（不安定 
衰 4 人気児童と排斥児童および孤立児童との遇晊能力の比校（男子）

\begin{tabular}{|c|c|c|c|c|c|c|c|c|c|c|c|}
\hline & \multicolumn{3}{|c|}{2 年 } & \multicolumn{3}{|c|}{4 年 } & \multicolumn{3}{|c|}{6 年 } \\
\hline & & & $\begin{array}{l}\text { 人叒児章 } \\
\mathrm{N}=12\end{array}$ & 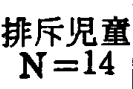 & $\begin{array}{l}\text { 每立児童 } \\
\mathrm{N}=12\end{array}$ & $\left\{\begin{array}{l}\text { 人児重 } \\
\mathrm{N}=1\end{array}\right.$ & $\begin{array}{c}\text { 排斥児童 } \\
\mathbf{N}=9\end{array}$ & $\begin{array}{l}\text { 坬立児童 } \\
\mathbf{N}=1\end{array}$ & $\begin{array}{l}\text { 人気児童 } \\
\mathrm{N}=15\end{array}$ & $\begin{array}{l}\text { 排哌児童 } \\
\mathbf{n}=1\end{array}$ & $\begin{array}{l}\text { 坬立児童 } \\
\mathrm{I}=12\end{array}$ \\
\hline 遇 功 & 能 力 & $\begin{array}{c}\mathbf{M} \\
(\mathrm{S} D)\end{array}$ & $\begin{array}{l}53.96 \\
(6.53)\end{array}$ & $\begin{array}{l}47.48 \\
(7.77)\end{array}$ & $\begin{array}{l}46.32 \\
(4.83)\end{array}$ & $\begin{array}{l}54.07 \\
(4.78)\end{array}$ & $\begin{array}{c}43.64 \\
(10.39)\end{array}$ & $\begin{array}{l}47.51 \\
(4.59)\end{array}$ & $\begin{array}{l}50.82 \\
(6.47)\end{array}$ & $\begin{array}{l}49.48 \\
(5.52)\end{array}$ & $\begin{array}{r}48.45 \\
(6.46)\end{array}$ \\
\hline
\end{tabular}

衰 5 人久児童と排斥児童および孤立児童との運動能力の比較（女子）

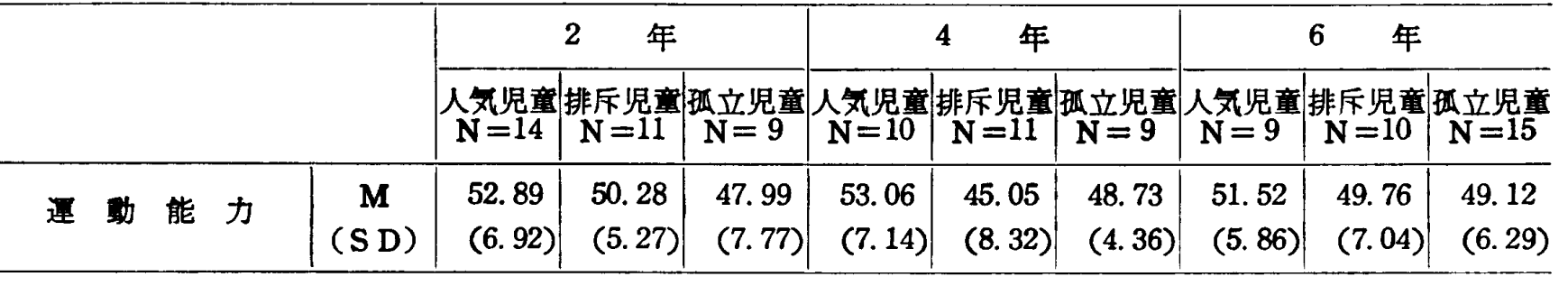

2 年男子

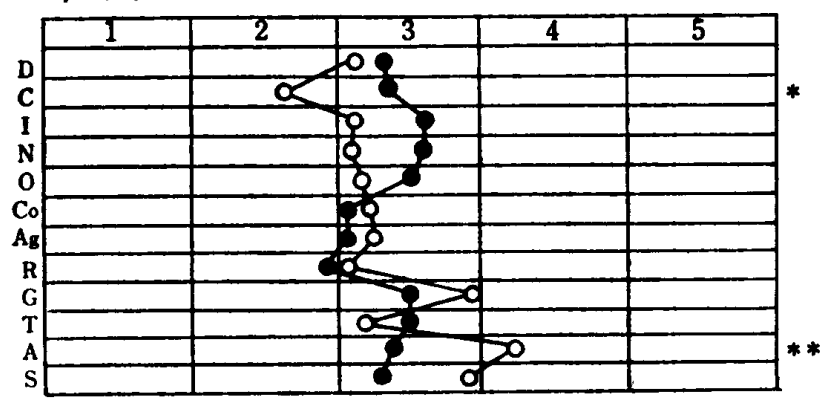

4 年男子

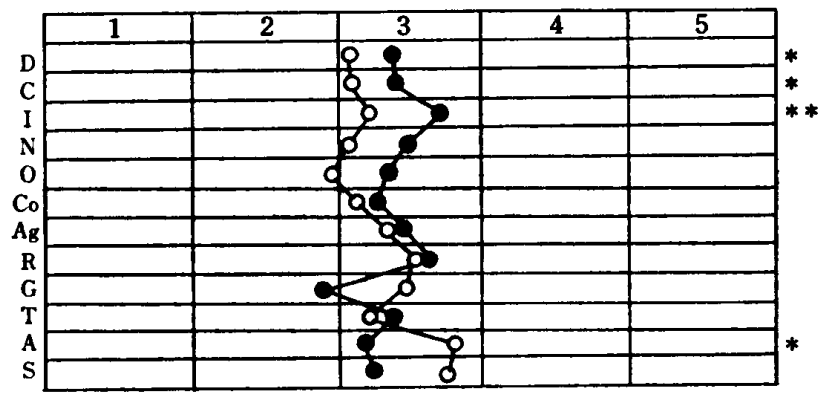

6 年男子

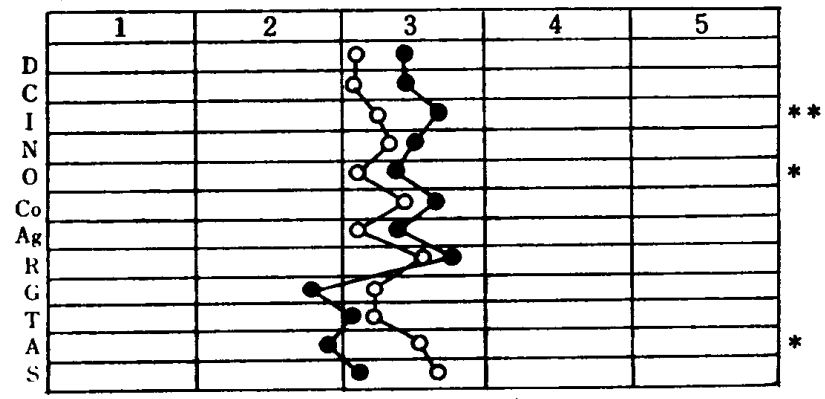

2 年女子

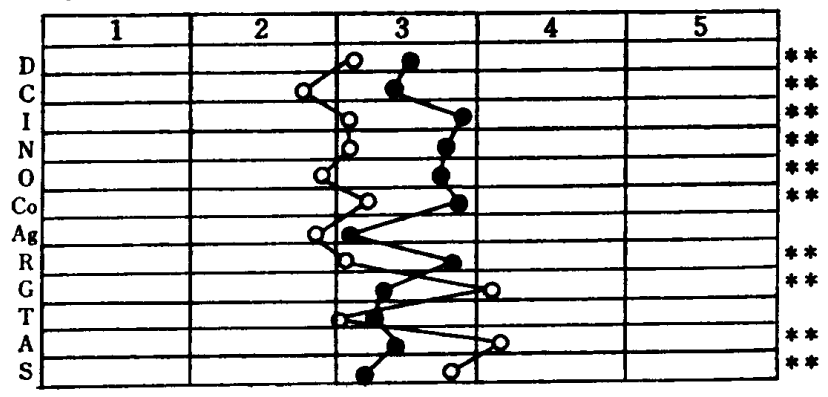

4 年女子

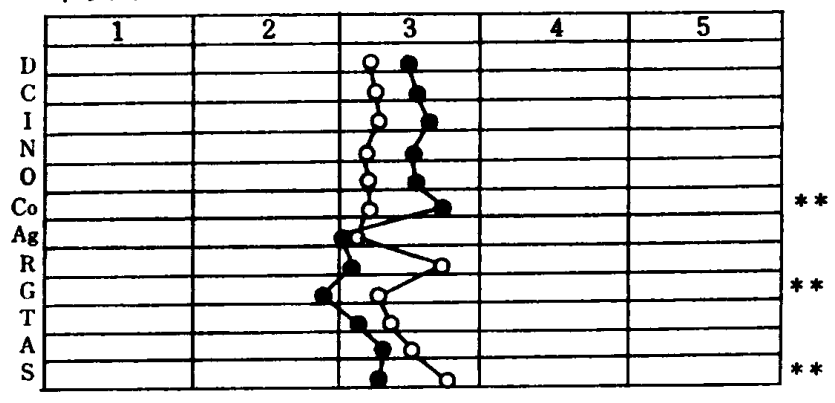

6 年文子

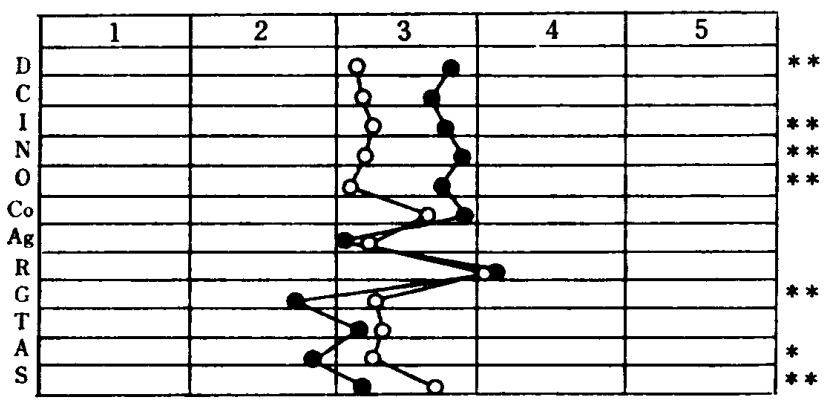

○一人上位群
下位群 $* * \mathrm{P}<.01 * \mathrm{P}<.05$

図 1 運動能力上位群と下位群の $Y-G$ プロフィールの比較 
消極）傾向を示している．男女別，学年別にそれ ぞれ尺度ことに両群の平均の差の有意性を検定し た結果， 2 年男子では C, $\mathrm{A}$ の 2 つの尺度で有意 差が認められた。すなわち，上位群は下位群より も気分の変化が少なく，指導性があるなどの特徵 がみられる、4 年男子ではD， C, I, Aの $4 つ$ の尺度で有意差が認められた。つまり，上位群は 下位群よりも抑 5 つ性, 気分の変化, 劣等感が少 なく，指導性があるなどの面をむっている，6年 男子では I，O，Aの 3 つの尺度で有意差が認め られた。すなわち，上位群は下位群よりも劣等感 が少なく，客観的で社会的指導性があるなどの面 をむっている．男子全体について尺度別にみる と, $\mathrm{A}$ の尺度はどの学年でむ, Cの尺度は 2 年と 4 年, I の尺度は 4 年と 6 年で有意差が認められ た。

2 年女子では, $\mathrm{Ag}, \mathrm{T}$ の 2 つの尺度を除く他の すべての尺度で有意差が認められた。すなわち， 上位群は下位群よりも情緒的に安定しており, 社 会的適応もよく，動作は活発で，指導性があるな ぞの面をるっている，4 年女子ではCo， G，Sの 3 つの尺度で有意差が認められた。つまり，上位 群は下位群よりも協調性があり, 動作は活発, 社 会的外向であるなどの面をるっている，6 年女子 では, D, I, N, O, G, A, Sなど 7 つの尺 度で有意差が認められた。すなわち，上位群は下
位群よりも抑 5 つ性, 劣等感, 神経質傾向が少な く, 客観的で, 動作は活発, 指導性をもち, 社会 的外向であるなどの面をもっている. 女子全体に ついて尺度別にみると， G， Sの 2 つの尺度はど の学年でも有意差が認められ， D, I, N , O, $\mathrm{A}$ の 5 つ 尺度は 2 年と 6 年で有意差が認められ た.

表 6 性格類型に上る運動能力の比較（男子）

\begin{tabular}{c|c|c|c|c|c|c}
\hline \multicolumn{2}{l|}{} & $\mathrm{A}$ 型 & $\mathrm{B}$ 型 & $\mathrm{C}$ 型 & $\mathrm{D}$ 型 & $\mathrm{E}$ 型 \\
\hline \multirow{2}{*}{2 年 } & $\mathrm{Mdn}$ & 47.72 & 49.85 & 50.74 & 53.84 & 45.67 \\
& $\mathrm{~N}$ & 18 & 5 & 9 & 6 & 6 \\
\hline \multirow{2}{*}{4 年 } & $\mathrm{Mdn}$ & 52.27 & 48.06 & 50.12 & 55.05 & 45.11 \\
& $\mathrm{~N}$ & 26 & 8 & 24 & 5 & 6 \\
\hline \multirow{2}{*}{6 年 } & $\mathrm{Mdn}$ & 53.37 & 48.64 & 50.22 & 52.16 & 45.46 \\
& $\mathrm{~N}$ & 19 & 6 & 21 & 7 & 6 \\
\hline
\end{tabular}

表 7 性格類型による運動能力の比較（女子）

\begin{tabular}{c|c|c|c|c|c|c}
\hline \multicolumn{2}{l|}{} & $\mathrm{A}$ 型 & $\mathrm{B}$ 型 & $\mathrm{C}$ 型 & $\mathrm{D}$ 型 & $\mathrm{E}$ 型 \\
\hline \multirow{2}{*}{2 年 } & $\mathrm{Mdn}$ & 49.85 & 44.06 & 51.01 & 55.98 & 47.72 \\
& $\mathrm{~N}$ & 17 & 4 & 19 & 5 & 6 \\
\hline \multirow{2}{*}{4 年 } & $\mathrm{Mdn}$ & 52.34 & 51.46 & 50.68 & 48.35 & 47.89 \\
& $\mathrm{~N}$ & 10 & 6 & 26 & 6 & 9 \\
\hline \multirow{2}{*}{6 年 } & $\mathrm{Mdn}$ & 52.15 & 46.03 & 48.54 & 54.93 & 50.49 \\
& $\mathrm{~N}$ & 16 & 6 & 12 & 10 & 20 \\
\hline
\end{tabular}

表 8 適応性棒断テストによる運動能力上位群と下位群の比較（男子）

\begin{tabular}{|c|c|c|c|c|c|c|c|c|}
\hline \multirow{2}{*}{\multicolumn{2}{|c|}{ 特 }} & \multirow{2}{*}{\multicolumn{2}{|c|}{ 性 }} & \multicolumn{2}{|c|}{ 運動能力上位群 $(\mathrm{N}=28)$} & \multicolumn{2}{|c|}{ 運動能力下位群 $(\mathrm{N}=28)$} & \multirow{2}{*}{$\begin{array}{c}\text { 上位群と下位群の比較 } \\
(\mathrm{t})\end{array}$} \\
\hline & & & & $\mathbf{M}$ & S D & $\mathbf{M}$ & SD & \\
\hline 1. & 異 & 傾 & 向 & 11.89 & 2. 36 & 10.00 & 2. 65 & 2. $78^{* *}$ \\
\hline 2. & 神 & 経 質 傾 & 向 & 10.35 & 3. 02 & 9.67 & 2.69 & 0.89 \\
\hline 3. & 自 & 尊＼cjkstart感 & 情 & 9. 46 & 3. 14 & 7. 14 & 3. 39 & $2.60^{*}$ \\
\hline 4. & 退 & 避 的 傾 & 向 & 10. 71 & 2.71 & 8. 32 & 2.78 & 3. $22^{* *}$ \\
\hline 5. & 自 & 己＼cjkstart統 & 制 & 9. 67 & 2.80 & 8. 28 & 2.56 & 1.90 \\
\hline 6. & 社 & 会 的 技 & 術 & 9.03 & 3.15 & 7.17 & 3.23 & 2. $14^{*}$ \\
\hline 7. & 統 & 率 & 性 & 8. 32 & 3. 66 & 5.14 & 2.86 & $3.57^{* *}$ \\
\hline 8. & 家 & 庭 関 & 係 & 10.60 & 3. 38 & 9. 78 & 3.17 & 0.92 \\
\hline 9. & 学 & 校 & 係 & 9. 85 & 2.74 & 7. 82 & 3. 36 & $2.44^{*}$ \\
\hline 10. & 近 & 隣 関 & 係 & 11.25 & 2.87 & 10.00 & 3. 60 & $2.44^{*}$ \\
\hline 適 & 応 & 性（総 & 点) & 100.68 & 19. 43 & 83.14 & 18.23 & 3. $17^{* *}$ \\
\hline
\end{tabular}


表 9 適応性跈断テストによる運動能力上位群と下位群の比校（女子）

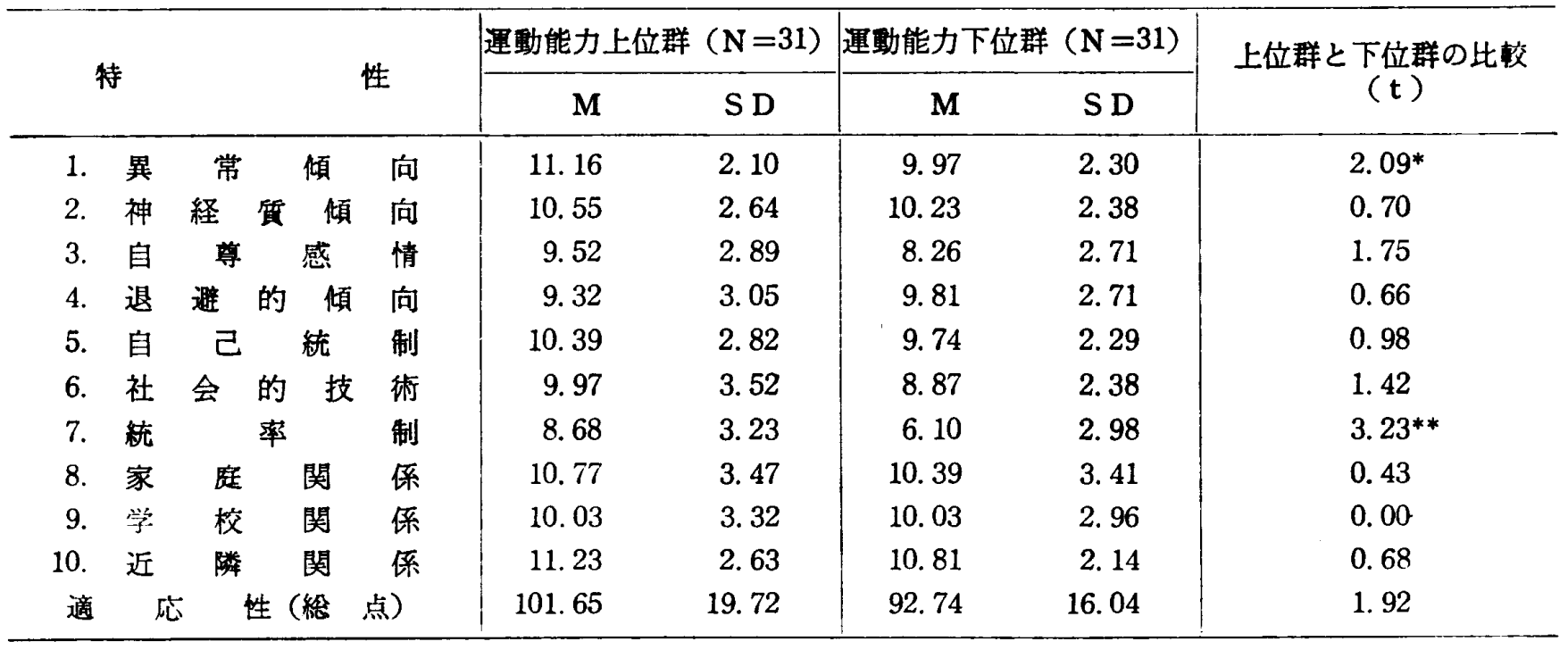

${ }^{* *} \mathrm{P}<.01{ }^{*} \mathrm{P}<.05$

次に性格類型から運動能力をみてみた。表 6 は 男子, 表 7 は女子の性格 5 類型の運動能力を比較 したものである。全体的にはD（安定積極）型の 成樍が良く, B (不安定積極) 型， E (不安定消 極）型の成績が悪い傾向がみられる．男女別，学 年別に Ryan の法を用いて各群の中央值の対比較 を試みた結果， 2 年男子の $\mathrm{D}$ 型と $\mathrm{E}$ 型の間でのみ $5 \%$ 水準で有意差が認められた（ $x^{2}=12.00 . \mathrm{df}$ $=1$ ).

\section{3. 運動能力と適応性の関係}

表 8 は男子, 表 9 は女子の 適応性診断テストの 10個の特性と総点について, 運動能力上位群と下 位群の平均值を求め, 両群の差の有意性の検定を 行なった結果を示したものである，男子では神経 質傾向，自己統制および家庭関係を除く異 常 傾 向, 自尊感情など 7 つの特性と総点で有意差が認 められた。つまり，上位群は下位群よりも自己に 対する適応と社会に対する適応が良好であり，心 理的にも調和した状態にあることを示している。 他方, 女子では異常傾向と統率性に有意差が認め られた。すなわち，上位群は下位群よりも情緒的 に安定しており，積極的な行動ができる状態にあ ることを示している。

次に適応群と不適応群の運動能力を比較してみ た。表10および表11で明らかなよ5に，男子，女 子ともに適応群が不適応群よりも運動能力で優れ ている.
表10 適応群と不適応群の運動能力の比較（男子）

\begin{tabular}{|c|c|c|c|c|}
\hline & 適応群 & $\begin{array}{l}\text { 不適応君 } \\
\mathrm{N}=28\end{array}$ & $\begin{array}{l}\text { 適応群と不適応群 } \\
\text { の比 }(\mathrm{t})\end{array}$ \\
\hline 軍動能力 & $\mathbf{M}$ & 51.08 & 46.52 & 2. $73^{* *}$ \\
\hline テスト & S D & 6. 32 & 5.98 & \\
\hline
\end{tabular}

${ }^{* *} \mathrm{P}<.01$

表11適応群と不適応群の運動能力の比較（女子）

\begin{tabular}{l|c|r|r|r}
\hline & $\begin{array}{r}\text { 適応群 } \\
\mathrm{N}=31\end{array}$ & $\begin{array}{l}\text { 不適応群適応群と不適応群 } \\
\mathrm{N=31}\end{array}$ \\
\hline -进動能力 & $\mathrm{M}$ & 52.24 & 48.44 & $2.52^{*}$ \\
テスト & $\mathrm{S} \mathrm{D}$ & 5.82 & 5.86 & \\
\hline
\end{tabular}

${ }^{*} \mathrm{P}<.05$

本研究では，児童の運動能力と心理的特性（社 会的地位，性格および適志性）との関係について 検討することをめさした。

運動能力と社会的地位との関係は, 男子では児 童期前期から後期にかけて，運動能力の優れた児 童が劣った児童よりる学級集団の中で好まれ，人 気を集めて扣り，また，学級の人気児童は，排斥 児童および孤立児童よりも運動能力で優れてい た。さらにこれらの傾向は高学年よりも低学年 で顕著であった。他方, 女子では, 児童期前期と 中期で男子とほほ同様な傾向が認められたが，児 
童期後期では，これらの傾向がみられなかった。 小学生男子を対象とした Clarke $5^{814}$ および中 学生を対象とした McGraw ら れていることが，集団の中で高い社会的地位を与 えられる重要な条件になると報告している，ま た, 石黒 ${ }^{6)}$ は, 巟童の遊び仲間として選ぶ理由の 1 つとして，身体運動能力の優秀なことをあげる 者が比較的多いこと,さらに，年龄が進むにつれ て, まじめ, 熱心, 責任感が強いなどの人格的要 因をあげる者が多くなることを指摘している，児 童にとって運動能力で優れていることは, 学級集 団の中で仲間の人気を集め, 承認されるための重 要な条件になるが, 逆に, 運動能力で劣っている ことは，遊びなどの場面で仲間とうまく交流でき なかったり，排斥されたり，孤立したりする要因 の1つになると言えよう．また，このような傾向 は高学年よりも低学年で，女子ょりも男子におい て顕著であると思われる. 特に女子の場合, 児童 期後期においては, 運動能力の優劣が学級内の交 友関係に，男子ほど影響を及ぼさないとの結果が 得られたが, この理由としては, 運動能力のもつ 生理学的, 心理学的意味が男子と女子とでは違っ ていること，および，女子に従順さを求める社会 的, 文化的背景などが考えられる

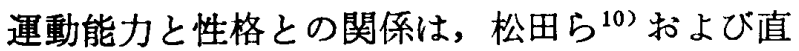
塚ら ${ }^{13)}$ の知見とほぼ一致する結果であった。すな わち, 男子と女子および学年によって多少の違い はあるが，運動能力の優れた児童は劣った児童よ りも劣等感, 気分の変化が少ないなど情緒的に安 定しており，社会的な接触を好み，指導性がある などの傾向がみられた。 また，プロフィールは， どの学年も運動能力の優れた群がやや右下がり傾 向(安定積極型)を示し, 劣った群はわずかに左下 がり傾向を示した。これらの結果は, 運動能力が 優れているということと, 児童の情緒安定性, 社 会的適応, 活動性などとが関連をむつことを示唆 している。 また，性格特性中 A（支配性）の尺度 が 4 年女子を除く他のすへてての学年で, G（活動 性）およびS（社会的外向）の尺度が女子のすへ ての学年で有意差が認められたのは注目される。 一方, 性格類型からみた運動能力は, 全体的にD （安定積極）型の成績が良く, B (不安定積極)
型, $\mathrm{E}$ (不安定消極) 型の成績の悪い傾向がみら れた。これは、性格類型と運動能力との間に, 一 定の関連があることを示唆していると思われる。

運動能力と適応性との関係は, 男子では, 運動 能力の優れた児童が劣った児童よりも，自己に対 する適応と社会に対する適応が良好であった。し かし，女子では男子ほど顕著な差が認められなか った。また，男子および女子の適応群は不適応群 よりも運動能力で優れていた。この結果は, 運動 能力の優劣が児童の適応のしかたと関連すること を示しており，特に男子の場合，運動能力の優れ た児童は劣っている児童よりも自己の基本的要求 が適度に充たされて，安定感を有し，また，自己 主張と社会的要求との調和が維持されていること を示唆している。

以上から，児童の運動能力の優劣は，交友関 係，性格および適応のしかたなどと密接な関連の あることが考えられる，今後は，これらの要因の 相互作用を分析するとともに，これらの因果関係 についても検討を加えていく必要がある.

\section{要約}

本研究では小学校 2 年, 4 年, 6 年の児童 637 名（男子 317 名，女子320名）を対象汇運動能力 テストと 3 つの心理検査 ( $\mathrm{Y}-\mathrm{G}$ 検查, sociometric test, 適応性診断テスト) を実施し, 運動能力と 心理的特性（社会的地位, 性格, 適忍性）との関係 について考察した，その結果は次のように要約さ れる.

1）運動能力の優れた児童は劣った児童よりも 学級集団の中で人気をあつめ，承認されており， また，学級集団の中で人気をあつめている児童 は，嫌われたり孤立している児童よりも運動能力 で優れていた。ささらに，これらの傾向は女子ょり も男子で, 高学年よりも低学年で顕著であった。

2）運動能力と性格との関係については若干の 男女差, 学年差が認められたが，運動能力の優れ た児童は劣った児童よりも情緒面で安定しており 動作も活発で，指導性があるなどの傾向が認めら れた。また，性格類型からみた運動能力は，全体 的に D (安定積極) 型の成樍が良く, B (不安定 積極）型およびE（不安定消極）型の成樍が悪い 
傾向がみられた。

3）運動能力と適応性との関係については，男 子において，運動能力の優れた児童が劣った児童 よりも自己に対する適応と社会に対する適応が良 好であった。しかし，女子では男子ほどに顕著な 差がみられなかった。

本研究の実施に当っては，八千代市立八千代台東小学 校の坂本宗三郎校長をはじめ諸先生方に，多大の御協力 をいただきました.深く感謝致します。

\section{文献}

1) Biddulph, L. G., "Athletic achievement and the personal and social adjustment of high school boys", Res. Quart. 25: 1 7, 1954.

2) Booth, E.G., "Personality trait of athletes as measured by MMPI," Res Quat, 29: 127 37, 1958.

3) Clarke, H.H. and D.H. Clarke, "Social status and mental health of boys as related to their maturity, structual and strength charactristics," Res. Quart., $32: 326 \sim 34,1961$.

4) Clarke, H.H. and W.H. Greene, "Relationships between personal-social measures applied to 10 year-old boys," Res. Quart., 34 : 288 98, 1963. 5) Fulton, R.E. and E.M. Prange, "Motor learning of highly chosen and unchosen teammates," Res. Quat., $21: 126 \sim 31,1950$.

6）石黒釤二「友人関係の発達一生活場面によるその变 動一」巟童心理，5：64７3，1951.

7) 清原健司, 上田雅夫「体育・スポーツ心理学の諸閣 題」心理学研究, 35：143 53, 1964.
8) MacGraw, L.N. and J.W. Tolbert, "Sociometric status and athletic ability of junior high school boys," Res. Quart., $24: 72 \sim 80,1953$.

9 ）松田岩男, 小学校 $1 \cdot 2$ 年生の運動能力テストとそ の判定基準, 光文書院, 1967.

10）松田岩男, 杉原隆, 海野孝「児童の体格・運動 能力・性格の関係について一発育道跡研究の資料分析 一」日本体育協会スポーツ科学研究報告, No. XIII, 1969.

11) Merriman, J.B., "Relationship of personality traits to motor ability," Res. Quart., 31: 163 73, 1960.

12）長島貞夫, 山崎 正, 藤原喜悦, 新訂適灾性㟝断テ スト解説，金子書房， 1975.

13）直塚鉄太郎, 新里紹正, 日高良広「小学校期の主と して体型・性格よりみたる運動能力の特性について （3 報）」体育学研究， $15 ： 62 ， 1971$ 。

14）日本体育協会, スポーツテスト実施要覧, 日本体育 協会, 1967.

15) Rarick, G.L. and R. McKee, A study of twenty third-grade children exhibiting extreme levels of achievement on tests of motor proficency, Res. Quart., 20:142 52, 1949.

16）高木貞二, 心理学研究法, 岩波書占, 1969. pp. $365 \sim 75$.

17）过岡美延, 新性格検查法--Y-G性格検查実施応用研 究手引一, 竹井機器工業, 1974 .

18) Tillman, K., "Relationship between physical fitness and selected personality traits," Res. Quart., 36: 483 89, 1965.

19）津留 宏, 性差心理学, 朝倉書店, 1970. 